\title{
SUSTAINABLE OPERATIONS AS A STRATEGY OF MANAGEMENT OF COMPANIES, WITH A REVIEW IN THE FIELD OF AGRICULTURE
}

\author{
Ljiljana Rajnović ${ }^{1}$, Snežana Cico $^{2}$, Jelica Eremić - Đorđić ${ }^{3}$ \\ *Corresponding author E-mail: rajnoviclj@gmail.com
}

A R T I C L E I N F O
Review Article
Received: 29 March 2019
Accepted: 12 June 2019
doi:10.5937/ekoPolj1902601R
UDC 631:[502.131.1:347.725

Keywords:

sustainable business, corporate governance, company goals, business crises, agriculture

JEL: Q14

\begin{abstract}
A B S T R A C T
The operation of companies on the domestic or international market implies, a well - organized company whose function is based on efficient business and, on the fiduciary duty of the owner and management, which is at the same time a challenge, but also a great responsibility in view of the interests of all constituents. The disadvantage or loss of these features in organizing the companies, leads to significant lagging of the company in relation to its competitors and the continuous weakening of economic power can lead to the collapse, which is the hardest blow to the investors but also the recognition of the manager that he was not successful. The agriculture is one of the most important sector of activity in Serbia, in the last hundred years, in terms of the volume of production and the number of engaged population, which is why sustainable business in this area is necessary.
\end{abstract}

(C) 2019 EA. All rights reserved.

\section{Introduction}

Many research studies applied in corporate governance practice (Vasiljević, 2013) state that a company is only at first glance an idyllic legal entity with one interest, the interest of the owner of the capital, regardless of whether the owner is one or a numerous of economic entities, legal entities, individuals or the state. On the contrary, a company is, in fact, a lot of conflicts and interests, both within the society itself and in relation to the outside world that surrounds it. Various business entities are interested in the permanent business and the survival of the company: shareholders, creditors, employees, management, the companies themselves, and the state in a sociological sense. They

1 Ljiljana Rajnović Ph.D., Institute of Agricultural Economics, Belgrade, Volgina 15, Phone: + 38163273 237, E - mail: rajnoviclj@gmail.com, ORCID ID (https://orcid.org/00000002-8209-9088)

2 Snežana Cico Ph.D., Severtrans ad Sombor, Filipa Kljajića bb, Phone: + 381644402057 , E - mail: snezanacico@gmail.com, ORCID ID (https://orcid.org/0000-0003-3356-6767)

3 Jelica Eremić - Đorđić Ph.D., Assistant Professor, Educons University, Faculty of Business Economics /EPS Elektrodistribucija doo Beograd, Bulevar umetnosti 12, Phone: + 38106483 72 738, E-mail: jelicaerdjo01@gmail.com, ORCID ID (https://orcid.org/0000-0003-2462-1672) 
all have their own interests in relation to a company, but also risks, depending on their relationship with society. Much of this is added to the interest of consumers, which is justified, although it is not based on a contractual arrangement with the company.

On the part of economics, several approaches to the economy were crystallized. According to the usual approach, the company is viewed as an economic entity in a market that transforms resources into economic goods (goods and services) that are sold on the market. The company's behavior is based on the choice of volume and structure of resources and produced productions, with the goal of establishing such prices and production volumes that would bring maximum profit.

And other theories (behavioral, evolutionary) emphasize the complexity of the company, i.e. the existence of various interest groups in it. One of the developed models, the agent problem (principal - agent), is based on the complexity of distinguishing the objective positions that the managers occupy within the company. From the aspect of this paper, this theory, which originates from A. Smith (Smith, 1776) and Berle \& Means (Berle \& Means, 1932), is of particular importance, and it is promoted in the work of Jensen and McKinley (Jensen \& Meckling, 1976).

\section{The obligation of a sustainable business of companies}

The time in which we exist is called the age of a creative economy. There are no routine answers for problems faced by businesses. Academic knowledge of individuals and institutions is no longer sufficient. In order to find the best answers, it is necessary to deepen the inner knowledge that lays sleeping in each individual and organization. Imperative success becomes the creative use of all knowledge. Just as nature creates, it is expected from every business entity and especially the management, to use good principles in their business life and work and turn every problem into a creative challenge.

The question is often raised to what extent the company is capable of mobilizing energy potentials of all available resources, including employees, and directing them to achieve common goals. It is indisputable that the quality and intensity of the company's energy essentially affect the overall results it achieves in its business.

The search conducted in practice on a sample of over hundred companies showed that with high productive energy companies, compared to those with low one:

- overall performances were higher by $15 \%$,

- $\quad$ productivity of employees by $17 \%$,

- customer loyalty by $12 \%$ and

- commitment is higher by $10 \%$.

At the deepest level, every company is a vibrant energy field whose vibrations affect the thinking, feelings and creativity of management and employees. The quality and intensity of the organizational field also affects the partners, business partners of the company and all those who come into business contacts directly or indirectly with the company. 
Energy, intelligence and creation clearly show the source of vitality and humanity and organization. All companies are initiate by vital energy and intelligence guides them. Cultivating vital energies represents a major step forward in the modern understanding of organization and management. The most important interest of all persons interested in the business of companies (constituents), but also the duty of the owner of the capital and managers, is to ensure successful and continuous performance of the company's activity, for an indefinite period of time and with constant growth, in order to ensure a secure survival in a constant turbulent environment. Nowadays companies are increasingly taking care of who they are doing business with, in order to maintain their reputation in the conditions of maximum transparency. Therefore, ninety-five percent of the two hundred and fifty world's largest companies regularly provide public reports on their sustainable development. In Serbia, pioneers in these practices of Delta, NIS, Holcim and Titan have taken on board their responsibilities towards the communities in which they work.

At the same time, standards are being developed in the field of reporting, and today more than eighty percent of the reports have been developed according to the Global Reporting Initiative (GRI) standards. Standards help to make reports comparable and meet common indicators in order to compete with competitors. Sustainable business reporting is becoming more and more subject of legislator attention, especially at the EU level, and the legal reporting obligation is already in place in France, Denmark and Sweden. Sustainability, which is nowadays called sustainable value creation, is the business imperative of the century. In the largest multinational corporations, all teams are assigned an obligation to tackle this issue. Economic sustainability is often the first type of sustainability that a company aspires to. How can companies' revenues cover the costs with sufficient residual income needed for business growth and satisfaction of the owner of the capital? The challenge is not to determine the priorities of a kind of sustainability in relation to the other, but to make fully conscious decisions, knowing the long-term and short-term consequences.

In addition to creating a sustainable business model that guarantees business survival, sustainability reports help companies to identify those processes that can make the business more efficient. They complement the image of the company and help potential investors or business partners to properly evaluate all business risks and value of cooperation. At the same time, this is one of the ways to improve the quality of relationships with different stakeholders, from employees across the local community to the government of the country's nationality of the company and beyond, and they have undoubted importance in the process of developing corporate strategies, but also developing new services and offering new products.

In this sense, the value of a company on regulated markets of developed world countries, above all Western Europe, is justified on the basis of the following, in business world of recognizable characteristics: successful and long-lasting business, originating from stable markets, properly carrying out its obligations. These are attributes that give one company a reputation and they find it recognizable in the market and a desirable partner in business cooperation. 
It is precisely, the main goal of each company is to ensure permanent, continuous business operations for an indefinite period of time, which in theory and practice appears as a written but also unwritten rule, that is, as an obligation of persons who, with their own decisions prevail influence on the organization and management of the company. The individual goals of the person interested in the company's business may or may not be different, and are largely defined by the ownership of the company. When we talk about a corporation that Jensen and Meckling (Jensen \& Meckling, 1976) define as "one form of legal fiction" that serves as a chain of contractual relationships, distinguished by dividing residual rights to assets and cash flows that can be sold without seeking permission from other contracting parties, we can to conclude that, in the opinion of these authors, the corporation is nothing more than a "chain of contractual relations" whose main purpose is to maximize value for shareholders, and not to satisfy the interests of other constituents and the wider community. All companies, in the basis of their existence, have a need for permanent and safe business and for an unlimited duration, although the goals that affect the core of their business are different.

In the countries of the continental system of law, to which our country belongs, the capital company is defined as a collection of several legal, and / or physical persons, associated with the aim, in addition to carrying out some commercial activity under a personal or real firm, on the basis of the association of certain capital, expressed in shares or shares, will achieve a certain profit, which will be distributed among themselves according to the criteria established by the founding agreement and the law. Under this system, the company has a lucrative goal and the legal presumption of commerciality, that is, the goal of forming capital companies is business to acquire and dispose of profits among the members of the company, with the prior payment of obligations towards all creditors and other persons interested in the business of the company. In economic literature it is undisputed that the company is the basic economic cell of society. Hence, all economists point to the foreground the two cornerstones of each company: the organizational aspect and the target aspect - profit.

The company, as a legal entity and the bearer of subjectivity, through which it acquires rights and obligations on the market, has several properties:

- the Enterprise represents the technique of contractual organization of members, for the purpose of joint performance of the agreed economic activity,

- the enterprise is a technique of organization as a societal form, which allows the separation of dedicated assets for the enterprise and easy transmission of the company through the transmission of membership rights (stakes and / or actions).

The enterprise is a technique for the organization of dedicated property, which is a part of the dogma of unity and indivisibility of the property (Cozian \& Viandier, 1998).

In support of the obligation of the company to maintain the continuity of business, the principle of fixedness and preservation of the integrity of capital of capital companies is also discussed. Although companies are established to earn profits, assets do not need 
to, or will not always increase, but can be reduced due to internal and external reasons due to loss in business. Since the capital companies do not have the responsibility of members for the obligations of the company (other than the initial and possibly later role of members in the company), this is extremely important for the creditors of the company, what is the adequacy of its capital, because the company must have a favorable relationship between its capital and borrowed capital, so-called, impaired capitalization is a bad signal for its liquidity. Therefore, the company's capital is entered into public registers that keep records of business subjects and this information must be publicly available to every interested person. In some countries, for example, Germany, the amount of capital is an integral part of the company's memorandum, and the nomination of non-nominal capital, as well as the other basis of capital increase, and in particular the basis and procedure of capital reduction, are in the constant focus of strict legal rules of registration and publication all over the world.

\section{The goals of the modern corporation and its managers}

All business activities undertaken by one company determine the overall impact of that company on society, including individuals, companies, the state and the environment. The positive and proactive performance of the business sector in all these areas has become an established practice in the developed world, primarily because it has been shown that such a practice benefits all persons interested in the business of the company, including the state. Increased accountability in business is shown not only as a necessity, but also a prerequisite for survival and development of the company.

Today, profitability is just one of the demands that the company's management has before itself. Profit is a necessary condition for the survival of all economic entities and serves multiple people. Sustainability or sustainable development represents an idea of development that meets current needs, but takes into account the needs of future generations. Economic sustainability for itself is not a sufficient condition for the longterm viability of a society. In this sense, responsible business represents one of the key solutions for achieving sustainable development and survival of the company, because it creates a balance between economic interests, as the main driver of development and the interests of the whole society.

According to the well-known principles of corporate governance, adopted in most countries of the world, the achievement of the company's target function - maximizing profits, that is, the company's value is the imperative of every company. It is widely known that in today's world the main goals of the modern corporation and its managers are: a) a stable and growing return on investment, a sustained cash flow and increased earnings; b) high income of the management with the possibility of worthy annual bonuses; c) growth and expansion of the corporation in order to expand business and market; d) good competitive position. These goals are in a causal and consequential relationship, and thus we come to the imperative activity of the corporation and its administration towards a constant increase in profit, as it maintains a safe life of the corporation. Profit is a means for the periodic and annual corporate dividends to be 
distributed to shareholders through a dividend, a reward for the results achieved by the Board, and a substantial part of accumulating for investment in new projects, or preserved in the case of aleatory or occasional cyclical economic events worldwide.

Everywhere in the world companies perform a very important function for each state and society as a whole, have a great impact on the community, so they have an obligation to act in the general social interest (Corbett, 2008), respecting the good rules of socially responsible business. The company's motto is based on following bases (Rajnović, 2013):

- $\quad$ successful,

- $\quad$ long and profitable business,

- $\quad$ be ethical and

- $\quad$ socially responsible.

The concept of corporate social responsibility was created primarily on the basis of voluntarism, and later turned into a field of legal obligation, somewhat. In addition, there exists the concept that, being socially responsible does not mean just fulfilling the legal orders, but also to go "beyond" that companies are obliged. Given the inefficiency of regulation and self-regulation, the question is can a corporation go beyond the law? It seems that this issue is not necessary with regard to the minimum regulation to ensure the efficiency of the business. Corporations should volunteer to do so, go beyond the law, and that is the essence of their social responsibility. It is believed that these corporations can do it anyway when such an investment (Vives, 2008), for example, greater investment in human rights protection than the legally prescribed minimum protection, greater protection of consumers from the legal minimum protection, higher investments in environmental protection, greater protection of other stakeholders besides the owner: employees, creditors, administration, local community, state (Elkington, 1998; Nica, 2018).

This approach has its direct starting point in increasing the productivity, profit and competitiveness of the company. In this way, the demands of the states regarding the company's commitment to social responsibility, from the idea that it was originally conceived, to apply only to the largest multinational corporations, were extended to small and medium-sized enterprises. In the event of a conflict of interest between maximizing profits and corporate social responsibility, the theory of social responsibility provides arguments that support the company's social responsibility, such as: 1) legal arguments - the company's social responsibility leads to the inability to interfere in its affairs and greater autonomy, 2) economic arguments - in the long run strengthens the company's identity and reputation in front of stakeholders, which is reflected in its economic position, 3) personnel arguments - Corporate Social Responsibility is capable of attracting more qualified staff and 4) ethical, companies have a general responsibility towards the society in which they function. 
If the aforementioned company responsibilities were presented in the form of a pyramid, the broadest basis and power would have:

1. economic responsibility, then

2. legal responsibility of the company, while after that it will come,

3. moral accountability at on the top, as the least in power and commitment of the company, would come,

4. charitable or philanthropic responsibilities, which reflect the smallest part of the company's social responsibility. Of course, the rule is that ethical and charity responsibilities are undertaken only if it increases the profit of the company. For example, "If a company donates to a director's wife, it is a conflict of interest and no economic effects, and as such is not permitted" (Nehme et al., 2008).

In support of the concept of social responsibility, the reasons for ethics and the reasons for marketing point out, but because both have their own economic expression in increasing profits. Nevertheless, "there is no basis for the claim that there is a proven view that the socially responsible behavior of companies inevitably leads to an increase in their profits" (Savkovic, 2009). It is considered to be a kind of investment, so-called. socially responsible investment, not the cost so that it has the impression that, as such, they are not enough (Besmer, 2006).

Namely, it is about the real condition without which there is no sustainable development of the company in the long term, nor the development and stability of the companies and each individual state. If sustainable development is to be achieved, then social responsibility must be accepted by companies. In the long run, companies can benefit from social responsibility because it plays a direct role in ensuring sustainable development (Herrmann, 2004). The concept of sustainable development is broader than the concept of corporate social responsibility (Vives, 2008).

In the market, everything is subordinate to the strengthening of the economic power of the company, because it is an essential component of the survival of not only individual companies, but also in the wider context and the status of a country with economically strong economic entities. Therefore, the most powerful companies with their economic power and the most powerful countries, often supported by the strength of their companies, use international politics and international institutions to demolish the barriers that stand in the way of their economic expansion all over the world.

In developed markets, the payment of dividends, the protection of minority shareholders, a clear and stable dividend policy are some of the basic premise of modern successful business. In Serbia, the number of companies that pay dividends, part of the gains to shareholders, owners of shares is still limited, while one part of the big companies did not go out on the stock market or think to leave. In Serbia, as well as in every country, the payment of profit is of great importance for the stability of the budget. As a dividend, any form of distribution of value that the capital company conducts to its 
shareholders or members is considered. Although dividends are primarily paid out in cash, they are not necessarily limited to that type of asset, but can also be paid in other assets, such as shares in other companies or the distribution of some other values.

The condition for the payment of a dividend is, above all, the profit of the company, which is why this data clearly indicates the profitability of one company and a positive attitude towards the shareholders. In addition, a clear dividend policy and the regular payments of profits, part profits to the owners of capital, are at the same time a sign of respect for the owners of capital, especially those of the minority, as well as a significant psychological message about the stability of an enterprise. At the same time, it is a call to investors to continue investing in the company's shares, as this will definitely make them profitable for a long time.

In this way, the dividend policy of the company becomes much more than the distribution of value and turns into a way in which responsible companies communicate with their shareholders and with the market. Therefore, the value of the company on the market is visible and connected with the dividend policy. The sudden change in this policy, especially in terms of restriction, almost as a rule brings down the value of the company's shares and creates certain distrust of investors and the environment. Therefore, responsible economic entities try to form a predictable dividend policy, and auditing it only when it is necessary or when they are convinced that they will be able to pay dividends to the shareholders over a longer period of time.

\section{Warning signals that jeopardize business continuity}

If the company is currently doing business successfully, that does not mean that it will be the same in the future, therefore, the performance cannot be guaranteed in the future, and the previous good business, no matter how long it lasts, is not a guarantor of future good results. By investing in an enterprise, the owner/investor is exposed to a certain risk, and depending on how much he is ready to take risks, he can opt for the type of activity that best suits him, who he is familiar with or who he or his manager has in his knowledge. It is known that companies with more risky investments potentially have higher returns, while those with a relatively conservative investment policy, which relate, for example, to preserve value, they have less returns, but investing in them invests even less risk.

Risks are the likelihood, or the possibility of adverse effects on the business and financial position of the entity. Risks can be systematic and non-systematic.

Systematic risk is one that the company has no influence, or very small, because this risk cannot be avoided by diversifying investments. Non-systematic risk is one that can be limited by diversification and the appropriate choice of investment or some other business policy measures.

All economic entities are in constant changes and turbulences that are caused by various factors, human, scientific, technological, political and the demands of nature. 
Restructuring, various types of reorganization, and other major changes are very common in trying to make companies grow to enormous rammers or survive.

Due to the inevitable changes caused by various reasons, business entities in their life cycle go through different stages, ups and downs, which necessarily require changes and adaptation to changes in newly emerging situations. For example. in the phase of growth of the company from small to medium, it is inevitable to move from an entrepreneur to a management organization. This change is very sensitive and is often realized with delay, especially in underdeveloped countries of the world that do not have sufficient knowledge.

Because of the above, it is obvious that the organization's transformation in contemporary conditions is a condition of the company's growth and development strategy, as well as the condition of its recovery and survival as well as success. In theory and practice of transformation, the change of organization is still most often used in crisis situations.

Organizational changes represent new challenges and requirements that are posed to all actors, including company management, employees and other constituents interested in the business of the company. If the change, especially in the conditions of the external crisis, is not managed in an adequate way, there are additional problems within the company itself, which certainly reflects on the business of the company (Rajnović, 2012). Employees in the companies certainly strive for job security, and hence their own stability and stability, and since changes often bring uncertainty, employees often face resistance to the unknown, according to the changes. In such situations, both capital owners and the management themselves need to introduce employees with the reasons for the changes, the essence of the change and the goal that is to be achieved, in order to provide the necessary readiness for changes without any or at all major disruptions of the work and business processes in the company.

It is expected from management, to predict timely crisis, external or internal, the possible operation of the crisis and other factors that may adversely affect the company's business and to has enough time, opportunities and knowledge to adapt it carefully by choosing methods and models of enterprise restructuring.

Regardless of external or internal causes of the occurrence and development of business disturbances, the problems in the company do not occur suddenly but cumulatively and more often, in individual areas and not in all parallel areas. This provides the opportunity for professionals to anticipate the crisis and timely precaution. The signs of the crisis, even those who are weak, must not be ignored. If the problem is fixed earlier it is resolved faster. If the crisis has progressed, and in the meantime, the necessary measures have not been taken, the responsibility is solely on the management of the company, since the owner of the company / investor is not in a position to adequately monitor the work of managers, because there is an asymmetry of information: namely, the manager knows more about the relevant matters from the owner, because he is a professional and because he is far closer to the business of the company than the remote owner. The owner, therefore, hires the managers because this other person has the necessary knowledge of the management of the company. 


\section{Internal signals of the crisis in the company's business}

In practice, very often until the crisis in the company comes not only due to disorders created in the external environment. Many companies have collapsed due to their internal problems. In previous practice, it has been shown that many of the more important causes of illiquidity and companies of internal character are. Unlike external conditions, the company can more easily and effectively influence the internal causes of business disruption, in order to halt the weakening of the company's performance, poor business results and ultimately prevent the collapse and failure of the company, if it sees a timely problem and has a sufficient management capability to take adequate measures restructuring.

The crisis is the result of poor financial results and management decisions, persons who can make timely decisions on the data from the financial statements, financial analysis done through different models. In the early 1970s, models such as the Altman model were developed, based on the analysis of traditional financial transactions. Over time, with the development of information technology, models such as "data mining", intelligent model and neural network techniques have been developed. Of the financial indicators, the most commonly used is the ratio of liquidity, indebtedness, loss, negative cash flow from business activities, and so on.

Signs or symptoms that indicate that a crisis has occurred, or the financial crisis has already come are numerous. A detailed analysis within the company itself, in particular the analysis of financial statements, is the basic tool used to identify these signals. Often it happens that non-financial signals give earlier information on the existence of a crisis, when it is noticed and all financial signals often happen that it is already in the advanced stage of the problem. Signals are those that enable us to realize the existential danger, their monitoring and analysis in a timely manner, in order to respond to the crisis, the causes have already led to such a situation, and they are identified in the next phase, the root of the problem is sought and resolved. The most important techniques for anticipating business failure and for early detection of potential crisis signals are: company's solvency, balance indicators, off - balance indicators, compliance of goals and results, gap analysis and others.

As internal causes of insolvency in enterprises most often occur: high costs of production and therefore the prices of products; inadequate management of the company lack of financial control; low level of productivity; lack of working capital; high rate of uncollectible receivables; permanent insolvency of the company; poor quality marketing and sales; high indebtedness of the company, etc. The cause of crisis situations often are the owners themselves, because of their unrealistic ambitious ambitions, wrong decisions regarding expansion, uneconomical diversification of activities by entering into unfamiliar business activities in different sectors of the economy, the desire for rapid development and fast pay, buying other enterprises with poor performance, overconfidence in existing management, ignorance, etc.

In many countries of a developed market, primarily in the United States, it is common practice before the adoption of a decision on the application of the appropriate crisis resolution model is most commonly introduced. crisis management that does not only 
presuppose the change of the existing management or the bringing of a new one, but the establishment of such an environment in a company that requires fast and focused action at all levels of the company. Existing management often changes because of the role it played in the timely identification of the onset and growth of the crisis, of its own mistakes that made it from neglect or ignorance. It is difficult to expect the same management to be able to propose and implement an adequate solution to the company's emergence from the crisis.

Operational risk is the likelihood of adverse effects on the business and financial position of the enterprise, and in the work of employees, inadequate internal procedures and processes, inadequate management of the information system and other systems, as well as due to unpredictable external events. With well-established procedures and internal controls, this risk can be avoided successfully.

\section{State of sustainable business in agriculture}

The backbone of the economy in the Republic of Serbia in the last hundred years, and still is, in terms of production volume and the coverage of the engaged population, makes agriculture, and therefore has a special role within the concept of sustainable rural development. Sustainable agriculture requires a systematic approach, that is, to look at agriculture as one of the most important areas of territorial development. It essentially represents the optimal balance of various production systems that, in accordance with the specific ecological conditions and economic interests of the stakeholders, fulfill more ecological, economic and social functions at the regional level. (Popović et. al., 2013).

Research has shown that high levels of rural poverty and unemployment are largely closely linked to the great reliance on rural areas in agriculture. For the restructuring and improvement of the economic base of rural areas, initiatives and efforts of all key subjects of sustainable rural development are necessary, since the insufficient influence of certain social groups can lead to the emergence of poverty, social exclusion and the threat to the cultural identity of business entities. Bearing in mind the experience of developed countries, it is clear that, in addition to supporting the development of agriculture, the policy of sustainable rural development must also focus on supporting the development of a non-agricultural economy due to inseparable business ties. Farmers' households in the United States, e.g. generate significant revenues from operations outside the farm. From agriculture, income from securities, interest on savings deposits, revenues from public programs, etc. It is known that the owner of a small enterprise or entrepreneur has a higher motivation for working and achieving positive financial results than managers of large companies, the best and most efficient use of resources, they have a better opportunity to produce small commodities and thus meet the demand for specific products, which is why they are interesting associates large companies.

Although rural areas of the Republic of Serbia have certain resources for successful 
implementation of the concept of sustainable development, there are numerous limiting factors of development, so major structural changes and significant material investments are needed in this very important area. According to UN Agenda 21 (Ch.14, 1992) of the Rio Conference on Sustainable Development of 1992, a new development approach was defined in the Sustainable Agriculture and Rural Development - SARD study. In accordance with the above act, the sustainability of agriculture and rural development ensures sustainable management of biological systems in agriculture (land, water, integral systems of plant nutrition and protection against pests and diseases, renewable energy sources and genetic resources), diversification of economic activities in small family farms in the rest of the local economy, which contributes to the increase of employment and quality of life in local communities, as well as the construction of infrastructure facilities, or the development of multifunctional agriculture, which can provide an environmentally friendly, economically efficient and socially responsible agricultural production, thus contributing to a sustainable territorial development. Of course, a prerequisite for the realization of the mentioned development concept is an integral policy of supporting multifunctional agriculture and sustainable development. In addition, good coordination with environmental policy, social policies and spatial and regional development policies is necessary, as well as strengthening bottom-up approach, especially in the management of natural resources.

In this process, the important role of science is most important, from which it is expected to provide a decisive contribution to the economic and social sustainability of agriculture, and thus to rural development, as well as the contribution to the whole country in the sociological sense in the future, because the necessary profitability of the agricultural sector can be provided only by innovations that can to bring about high yields in agriculture.

The process of transition of the agrarian sector in the Republic of Serbia started more than twenty years ago and significantly changed its structure. However, compared to other developed European countries, agriculture in the Republic of Serbia is still at the bottom of the scale. Although many strategic documents of the Republic of Serbia point to the great importance of rural areas in terms of dominant territorial representation, the number of inhabitants engaged in this activity, the availability of natural and anthropogenic resources, the participation of agriculture in employment, GDP and exports is still unsatisfactory and the state is still has not created a sufficient incentive environment for the development of this area.

The former dominance of large agricultural farms and cooperatives, in particular, replaced the new ownership structure of Serbian agriculture, in which new owners of agricultural land, private companies, have huge land holdings, are incomparably larger than they had before the Second World War on the territory of the former Yugoslavia. The final results of privatization for Serbian agriculture are not favorable. Out of a total of 253 privatized companies in the period from 2001 to 2012, a significant number ceased to exist due to illiquid business, bankruptcy, in over 50 companies a contract for the sale of social capital was terminated, which was concluded in the privatization process of privatization entities whose activity was related for agriculture, and a significant number of employees in these companies was left unemployed (Bukvić, 2018). 


\section{Conclusion}

If the persons with the greatest responsibility in managing the company, the managers and the majority owners of the capital, act as their law requires, while respecting the fiduciary duty towards the company, it is possible to ensure the stability of the company's business in the long term and, of course, if the management of the company is regulated in accordance with generally known principles of good corporate governance, which are applied in developed countries of the world. Profitability is the main basis for realizing the success and growth of the company. It represents the goal not only of the company, but of all other persons interested in the business of the company, including the state and the environment.

Therefore, it proved that is inevitable to introduce to every company of good corporate governance rules in order to regulate and respect the accountability system. Conscientious and responsible behavior, together with conscientious risk management and internal controls within a company, can identify potential problems before a serious crisis of business takes place, to take adequate measures, which creates favorable conditions for maintaining a lasting business of the company.

Legal systems of the world of the world, within which national legislation has different approaches, practices and a normative framework for solving these problems, are similar. Some insist on protecting small equity holders while limiting the role of large, and others strengthening management control by major shareholders. The practice of the oldest capital markets in the world, the United Kingdom and the United States, has shown that the regulation of these conflicting interests are possible in companies where there are a large dispersion of shareholders, and the imposing economic positions of many American corporations nevertheless show that a balance of different goals, primarily the owners of capital and managers, but also other stakeholders, found.

Possible solutions to the agent problem can be based on a number of basics: (Rajnović \& Bukvić, 2017), a reliance on the desire of managers to gain and preserve their own business reputation, in order to increase the price of their knowledge on the market, 2) contracting various incentive schemes to reward managers for the company's good results 3 ) clear definition of the fiduciary duty of the manager to the company followed by lawsuits in the event of a breach of duty, 4) a good system of control over the work of managers, 5) consolidation of shareholding or partial concentration of ownership and control in the hands of several major investors, 6) protection of the rights of minority shareholders, 7) which is considered a disciplining factor for management, 8) hostile takeover of the company, 9) the struggle for the shareholders' votes at the assembly, especially in the event of large dispersion of shareholding.

In this regard, regulations and well-known good practices, which regulate the provision of this area, should be conceived in accordance with the best international practices in the regulation of these institutions and in a uniform, recognizable way throughout the world. Then, the inclusion, integration and fitting of the theoretical and practically 
established regularities in the certain system of information of all economic entities, existing or newly formed, is followed. At the same time, the formation of behavioral habits - the stereotype based on the established good regularity in the event, the formation of faith in the correctness of the usual behavior, beliefs, in a word, form a good, generally known and applicable practice. At the same time, it is necessary to anticipate a set of control mechanisms that increase the safety of business operations, including the protection of investment funds from fraud and abuse in the business of the company.

\section{Acknowledgements}

Paper is a part of research within the project No. III 46006 - Sustainable agriculture and rural development in the function of accomplishing strategic objectives of the Republic of Serbia in the Danube region, financed by the Ministry of Education, Science and Technological Development of the Republic of Serbia.

\section{Conflict of interests}

The authors declare no conflict of interest.

\section{References}

1. Berle, A. A. \& Means, G. C. (1932). Modern Corporation and Private Property, Transaction Publishers, New York.

2. Besmer, V. (2006). The Legal Character of Private Codes of Conduct: More than Just a Pseudo-Formal Gloss on Corporate Social Responsibility. Hasting Business Law Journal 2(1), 279-306.

3. Bukvić, R. (2018). One hundred years of agriculture in Serbia 1918 - 2018 (on Serbian), Society for Economic History, Belgrade.

4. Corbett, A. (2008). Corporate Social Responsibility - Do We Have Good Cause to be Sceptical About it? Griffith Law Review, 17(1), 413-432.

5. Cozian, M., \& Viandier, A. (1988), Droit des societes, Litec, Paris.

6. Elkington, J. (1998). Cannibals with Forks: The Triple Bottom Line of 21st Century Business, North Macanto, Capstone Publishing.

7. Jensen, C. M., \& Meckling, H.W. (1976). Theory of the firm: Managerial Behavour, Agency cost and Ownership Structure. Journal of Financial Economics, 3(4), 305360 .

8. Nica, E. (2018). Gig-based working arrangements: Business patterns, labormanagement practices, and regulations. Economics, Management, and Financial Markets, 13(1), 100-105.

9. Popović, V., Sarić, R. \& Jovanović, M. (2013), The state and possibilities for the development of sustainable agriculture and rural development in the Danube Region (7-37), Sustainable agriculture and rural development - conceptual starting 
points, Belgrade, Institute of Agriculture Economics.

10. Rajnović, Lj. (2012). Principles of Corporate Governance (in Serbian), Law and Economy, ISSN 0354 - 3501, UDK 347.7, 240 - 249.

11. Rajnović, Lj. (2013). Socially responsible business in the function of improving the economic environment in the Republic of Serbia (on Serbian). Association of economists of Belgrade, Belgrade.

12. Rajnović, Lj. \& Bukvić, R. (2017). Corporate governance as part of the company's business strategy of companies (on Serbian). Belgrade: Institute of Agricultural Economics.

13. Savković, V. (2009), Corporate social responsibility - from moral to legal obligation. Legal Life, 532(12), 425-436.

14. Smith, A. (1776). An Inquiry into the Nature and Causes of the Wealth of Nations. London: W. Strahan and T. Cadell.

15. Vasiljević, M. (2013). Corporate governance, Belgrade, University of Belgrade, Faculty of Law.

16. Vives A. (2008). Corporate social responsibility: The role of law and markets and the case of developing countries. Chicago - Kent Law Review, 83, 199-229.

17. Nehme, M., \& Koon C. G. W. (2008). Tracing the Historical Development of Corporate Social Responsibility and Corporate Social Reporting. James Cook University Law Review, 15 (1), 129-168. 